\title{
Studi Kekerabatan Padi Hasil Piramidisasi Berbasis Marka Molekuler dan Fenotipik
}

\author{
Reisyi Rinola Tambunan ${ }^{1}$, Santika Sari ${ }^{2}$, Yoana Saragih ${ }^{1}$, Nono Carsono ${ }^{2 *}$ dan Noladhi \\ Wicaksana ${ }^{2}$ \\ ${ }^{1}$ Program Magister Agronomi, Fakultas Pertanian, Universitas Padjadjaran \\ ${ }^{2}$ Departemen Budidaya Pertanian, Fakultas Pertanian, Universitas Padjadjaran \\ Jl. Raya Bandung-Sumedang KM-21, Jatinangor 45363 \\ *Alamat korespondensi: n.carsono@unpad.ac.id
}

\begin{abstract}
Study of relationship of piramyded rice genotypes based on molecular and phenotypic markers
\end{abstract}

Gene pyramiding is an attempt to combine some favorable genes from many parents into one single genotype. High yield, resistant to brown planthopper, medium amylose content, early maturity and aromatic are among traits that expected to be combined in order to fulfill preference of farmers and consumers. A number of 28 of pyramided rice lines have been obtained, however assessment of their genetic relationship has not been conducted yet which is important for consideration to continue to the next breeding steps. The combination of these genes was accomplished by hybridization of many genotypes of parents with superior traits namely Sintanur (aromatic), Pandan Wangi (aromatic), IR64 (moderate amylose content), PTB33 (brown planthopper resistant), Ciapus (high yielding) and KA (early maturity). The objective of the experiment was to obtain genetic relationship among rice lines assessed by molecular and phenotypic markers. XLSTAT2016 software was employed to assess a Jaccard's similarity coefficient for molecular markers and Pearson's correlation coefficient for agro-morphology traits, meanwhile clustering was done by using UPGMA (Unweighted Pair Group Method with Arithmetic Mean). By molecular characterization, 41.3 percent of similarity and two groups were formed by 11 molecular markers that are closely linked to seven target traits. Meanwhile the grouping based on 14 agro-morphological traits formed three groups with $22.2 \%$ similarity. Genotype SPxCAKA1B, SPxPP3B dan PPxIP4B can be used as the promising parent for next hybridization because it has the farthest genetic distance among genotypes.

Keywords: Jaccard's similarity coefficient, Gene pyramiding, UPGMA, Pearson's correlation coefficient

\begin{abstract}
ABSTRAK
Piramidisasi gen adalah upaya untuk menggabungkan beberapa gen yang menguntungkan dari banyak tetua menjadi satu genotipe tunggal. Hasil tinggi, tahan terhadap wereng cokelat, kandungan amilosa sedang, umur genjah dan aromatik adalah beberapa sifat yang diharapkan untuk digabungkan. Melalui teknik piramidsasi, telah diperoleh 28 genotip, namun analisis kekerabatan genetik, sebagai pertimbangan dalam pengambilan keputusan pada tahapan pemuliaan selanjutnya, belum dilakukan. Kombinasi gen ini dicapai dengan persilangan banyak genotipe tetua dengan karakter unggul yaitu Sintanur (aromatik), Pandan Wangi (aromatik), IR64 (kandungan amilosa sedang), PTB33 (tahan wereng coklat), Ciapus (hasil tinggi) dan KA (umur genjah). Tujuan percobaan ini adalah untuk memperoleh hubungan genetik genotip dalam sifat-sifat agromorfologi dan marka molekuler. Analisis hubungan kekerabatan antara tetua dan 28 genotip piramidisasi dilakukan menggunakan software XLSTAT2016 untuk membentuk matrik similarity shared allele distance dengan koefisien Jaccard sebagai pembentuk jarak genetik untuk marka molekuler dan koefisien korelasi pearson untuk marka fenotipik. Kemudian dilakukan pengelompokan atau clustering dengan metode Unweighted Pair Group Method with Arithmetic
\end{abstract}


Averages (UPGMA). Hasil pengelompokan berdasarkan marka molekuler dengan menggunakan 11 marka yang terkait erat dengan tujuh karakter target, diperoleh koefisien kemiripan sebesar 41,3\% dan terbentuk dua kelompok, sedangkan hasil pengelompokan berdasarkan marka fenotipik dengan 14 karakter agro-morfologi terbentuk tiga kelompok dengan tingkat kemiripan 22,2\%. Genotipe SPxCAKA1B, SPxPP3B dan PPxIP4B dapat dimanfaatkan sebagai tetua atau genotipe harapan karena memiliki jarak kekerabatan yang paling jauh diantara genotip lainnya.

Kata Kunci: Koefisien kekerabatan Jaccard, Piramidisasi gen, UPGMA, Koefesien korelasi Pearson

\section{PENDAHULUAN}

Indonesia menjadi negara yang mengonsumsi beras paling tinggi di Asia mencapai 110-114 kg/kapita/tahun (Badan Pusat Statistik, 2015). Sementara itu pertumbuhan produksi padi selama 37 tahun menunjukkan ketidakmampuan untuk menutupi kebutuhan pangan Indonesia (Kusmana dkk., 2017). Lebih jauh lagi, menurut Direktorat Tanaman Pangan pada tahun 2017-2018 serangan hama wereng cokelat menyebabkan gagal panen di daerah sentra padi nasional. Pengembangan benih padi yang memiliki karakter produktivitas tinggi, tahan wereng cokelat, aromatik dan umur genjah merupakan solusi dari permasalahan tersebut. Saat ini pengembangan benih pemuliaan mengarah pada produktivitas dan karakter mutu beras (eating quality). Karakter mutu beras diantaranya adalah kandungan amilosa, konsistensi gel, temperatur gelatinisasi (), kandungan protein dan aroma (Fan et al., 2005; Jin et al., 2010).

Program pengembangan varietas yang umum dilakukan adalah melalui metode persilangan (hibridisasi) seperti, single cross, double cross, dan top cross. Namun, persilangan tersebut hanya mengarah pada pengembangan satu sampai tiga karakter target dalam genotip tunggal. Piramidisasi merupakan upaya penggabungan beberapa gen yang diinginkan dari beberapa tetua untuk menghasilkan suatu genotip unggul yang dapat dilakukan melalui metode persilangan atau melalui teknik transfer gen (Francis et al., 2013; Ye \& Smith, 2008). Akan tetapi saat ini teknologi transfer gen melalui Partcile bombardment dan Agrobacterium terbatas pada jumlah gen yang ditransfer dan hanya efektif untuk penyisipan sekuens DNA hingga $25 \mathrm{~kb}$ (Pink \& Puddephat, 1999), sehingga metode yang bisa ditempuh dalam penggabungan beberapa gen adalah melalui persilangan. Walaupun memang tidak hanya gen-gen yang diharapkan, gen-gen yang tidak diharapkan juga ikut terwariskan pada keturunannya.
Umumnya teknik piramidisasi yang telah dilakukan hanya berfokus pada karakter secara vertikal yaitu ketahanan terhadap beberapa patogen/hama dengan strain/biotipe (Hittalmani et al., 2000; Katiyar et al., 2001; Singh et al., 2001; Narayanan et al., 2002; Joseph et al., 2004; Sharma et al., 2004; Kumaravadivel et al., 2006). Sementara itu, penelitian sebelumnya pada riset ini telah berhasil menggabungkan beberapa karakter unggul secara horizontal diantaranya komponen hasil tinggi (bobot bulir tinggi, jumlah malai banyak, malai panjang), umur genjah, kualitas mutu beras baik (kandungan amilosa sedang dan aromatik) serta memiliki ketahanan terhadap hama wereng coklat ke dalam satu genotip harapan yang memiliki karakter morfoagronomi yang unggul (Carsono dkk., 2012; Carsono et al., 2013; Carsono dkk., 2016; Sari dkk., 2013; Tambunan dkk., 2016). Kombinasi gen diperoleh dengan menyilangkan beberapa genotip tetua dengan karakter unggul diantaranya Sintanur, Pandan wangi, IR64, PTB33, Ciapus, KA, genotip SP87-4 (Sintanur x PTB-33), PP48-3 (Pandanwangi x PTB-33), IP158-5 (IR64 x PTB-33), dan CAKA41 (Ciapus x KA).

Penggabungan beberapa gen dari populasi heterozigot yang berasal dari beberapa tetua yang berbeda menjadi genotip tunggal akan meningkatkan keragaman genetik yang lebih besar (Shamim \& Singh, 2017). Oleh karena itu, kombinasi marka fenotipik dan genotipik akan sangat membantu mengidentifikasi, memilih karakter yang diinginkan dan mempercepat seleksi (Ye \& Smith, 2008). Hal ini terkait dengan fakta bahwa marka molekuler merupakan salah satu teknologi yang dapat membantu analisis keragaman genetik dan mengonfirmasi gen target secara efektif dan efisien karena dapat meningkatkan reliabilitas (keterhandalan), tidak dipengaruhi faktor lingkungan dan fenomena epistasis (Collard \& Mackill, 2008; Bahagiawati, 2012), tipe sel dan fase pertumbuhan tanaman. Oleh karena itu, keberhasilan piramidisasi dalam menggabungkan beberapa gen dapat diketahui secara lebih akurat. 
Selain itu, evaluasi secara fenotipik juga diperlukan karena individu yang terseleksi dengan marka molekuler belum tentu memiliki karakter agronomi yang diharapkan. Evaluasi fenotipik dilakukan meliputi pengamatan karakter morfo-agronomis untuk mengetahui apakah karakter yang diinginkan terekspresi pada genotip hasil piramidisasi.

Padi hasil piramidisasi yang telah disilangkan dan terkonfirmasi memiliki beberapa gen target, selanjutnya dianalisis hubungan kekerabatan berdasarkan analisis kemiripan genetik. Menurut Weeden dan Wendel (1989), analisis kemiripan genetik berdasarkan karakter agronomi dan morfologi mempunyai beberapa kelemahan seperti pengaruh faktor lingkungan yang cukup besar, dan interaksi gen dominan resesif, namun setidaknya analisis ini tetap dapat menggambarkan adanya variabilitas genetik, oleh karena itu, maka analisis kekerabatan dilakukan berdasarkan marka molekuler, sehingga dapat diketahui informasi tentang konstitusi genetik dari tiap kelompok genotip yang terbentuk.

Sistem pengelompokan (clustering) diketahui dapat membantu dalam mengidentifikasi dan menganalisis penampilan suatu genotipe (Bennett, 1997). Hasil riset piramidisasi sebelumnya telah diperoleh 28 genotipe padi yang belum diketahui kekerabatannya secara genetik. Penelitian ini bermanfaat dalam pengambilan keputusan terkait genotip-genotip harapan yang akan dilanjutkan pada generasi berikutnya. Penelitian ini bertujuan untuk mendapatkan informasi hubungan kekerabatan dari 28 genotip padi hasil piramidisasi karakter (daya hasil tinggi, tahan wereng cokelat, umur genjah, aromatik, dan kandungan amilosa sedang) melalui marka molekuler dan karakter agro-morfologi.

\section{BAHAN DAN METODE}

Percobaan ini dilaksanakan pada bulan Maret 2016 hingga Oktober 2016 yang berlokasi di Rumah Plastik Kebun Percobaan Ciparanje dan di Laboratorium Analisis dan Bioteknologi Tanaman Fakultas Pertanian Universitas Padjadjaran. Metode percobaan yang digunakan adalah eksperimental dengan rancangan percobaan tanpa tata ruang, karena kondisi materi genetik yang berbeda setiap individunya. Materi genetik yang digunakan dalam penelitian ini yaitu 28 genotip $F_{1}$ hasil piramidisasi dan empat genotip tetua ( $F_{4}$ hasil persilangan yang telah terseleksi secara molekuler dan fenotipik). Total satuan percobaan sebanyak 32 tanaman.
Ekstraksi DNA menggunakan metode CTAB (Cetyl trimethylammonium bromide) (Doyle \& Doyle, 1987) dengan sedikit modifikasi. Pengujian kualitas DNA dianalisis dengan menggunakan 0,8$1,0 \%$ gel elektroforesis pada tegangan $100 \mathrm{~V}$ selama 30 menit dan divisualisasi menggunakan UV transiluminator untuk melihat baik atau tidaknya kepekatan dan kejelasan DNA. Amplifikasi DNA dilakukan menggunakan mesin Polymerase Chain Reaction (PCR) dengan komponen PCR berupa 9,5 $\mu L$ KAPA2G1M Fast Ready Mix DNA polymerase $\left.(0,25 \mathrm{U}), \mathrm{dNTPs}(0,2 \mathrm{Mm}), \mathrm{MgCl}_{2}(1,5 \mathrm{Mm})\right), 1 \mu \mathrm{L}$ primer forward dan reverse, serta $1 \mu \mathrm{L}$ template $(20$ ng DNA). Analisis molekuler menggunakan 11 marka molekuler yang terkait erat dengan karakter target (Table 1). Produk hasil amplifikasi PCR dielektroforesis menggunakan 1,5\%-3,0\% gel agarose dan/atau $8,0 \%$ Polyacrylamide Gel Electrophoresis (PAGE) dalam larutan buffer 0,5x TBE yang di running pada durasi waktu dan besaran tegangan listrik tertentu. Hasil visualisasi DNA dideteksi melalui UV transiluminator (Geldoc) dan sebagai standard digunakan 100bp DNA ladder (Promega) untuk menetapkan ukuran pita hasil amplifikasi DNA.

Marka molekuler diamati melalui pola pita DNA dengan bantuan software Genetools. Skoring dilakukan berdasarkan ukuran molekul DNA yang terbaca oleh software Genetools dan telah distandarisasi dengan ladder $100 \mathrm{bp}$. Marka fenotipik diamati melalui pengamatan karakter morfoagronomi, diantaranya karakter komponen hasil yaitu tinggi tinggi tanaman, jumlah anakan total, jumlah anakan produktif, jumlah gabah total per malai dan bobot 100 biji dan diberi skoring berdasarkan standar International Rice Research Institute (IRRI) and International Board for Plant Genetic Resources (IBPGR; 1980). Pengamatan karakter umur genjah melalui pengamatan umur bunting, umur keluar malai, umur berbunga dan umur panen. Karakter aromatik diamati berdasarkan uji sensori menggunakan $\mathrm{KOH} \mathrm{1,7 \%} \mathrm{(Sood} \mathrm{\&} \mathrm{Siddiq,}$ 1978). Karakter tahan wereng cokelat diamati berdasarkan kerapatan trikoma menggunakan mikroskop binokuler dengan perbesaran 40x10.

Analisis hubungan kekerabatan antara tetua dan 28 genotip piramidisasi dilakukan menggunakan software NTSYSpc 2.11X untuk membentuk matrik similarity shared allele distance dengan koefisien euclidean distance sebagai pembentuk jarak genetik untuk marka molekuler fenotipik. Selanjutnya dilakukan pengelompokan atau clustering dengan metode Unweighted Pair Group Method with 
Arithmetic Averages (UPGMA) menggunakan mengetahui kekerabatan diantara genotip hasil SAHN clustering. Hasil pengelompokan piramidisasi. digambarkan sebagai sebuah dendogram untuk

Tabel 1. Marka molekuler yang digunakan dalam penelitian

\begin{tabular}{|c|c|c|c|c|c|c|c|}
\hline \multirow[t]{2}{*}{ Karakter } & \multirow{2}{*}{$\begin{array}{c}\text { Marka } \\
\text { molekule } \\
\mathrm{r}\end{array}$} & \multirow[t]{2}{*}{ Linked to } & \multirow[t]{2}{*}{ Chr. } & \multicolumn{2}{|c|}{ Sekuens Primer } & \multirow{2}{*}{$\begin{array}{c}\text { PCR } \\
\text { product } \\
\text { size }\end{array}$} & \multirow[b]{2}{*}{ Referensi } \\
\hline & & & & $\begin{array}{l}\text { Forward } \\
\left(5^{\prime}-3^{\prime}\right)\end{array}$ & $\begin{array}{c}\text { Reverse } \\
\left(5^{\prime}-3^{\prime}\right)\end{array}$ & & \\
\hline Bobot Bulir & RM282 & GW3 & 3 & $\begin{array}{l}\text { gctccacctgctta } \\
\text { agcatc }\end{array}$ & $\begin{array}{l}\text { tgaagaccatgtt } \\
\text { ctgcagg }\end{array}$ & $\begin{array}{c}162-226 \\
\text { bp }\end{array}$ & $\begin{array}{l}\text { Hai mei et } \\
\text { al. (2011) }\end{array}$ \\
\hline Jumlah malai & RM259 & & 1 & $\begin{array}{l}\text { tggagtttgagagg } \\
\text { aggg }\end{array}$ & $\begin{array}{l}\text { cttgttgcatggtg } \\
\text { ccatgt }\end{array}$ & $162 b p$ & $\begin{array}{c}\text { Gramene } \\
(2016)\end{array}$ \\
\hline $\begin{array}{l}\text { Panjang malai } \\
\text { (LP) }\end{array}$ & RM3600 & $L P 1$ & 9 & $\begin{array}{c}\text { tgcccacacatgat } \\
\text { gagc }\end{array}$ & $\begin{array}{l}\text { aacgggcaagag } \\
\text { atcttctg }\end{array}$ & $130 \mathrm{bp}$ & $\begin{array}{l}\text { Gramene } \\
\text { (2016) }\end{array}$ \\
\hline $\begin{array}{l}\text { Panjang malai } \\
\text { (SP) }\end{array}$ & RM3701 & $S P 1$ & 11 & $\begin{array}{l}\text { gagctagagggag } \\
\text { gaggtgc }\end{array}$ & $\begin{array}{l}\text { ttgactgatagcc } \\
\text { gattggg }\end{array}$ & $174 \mathrm{bp}$ & $\begin{array}{l}\text { Gramene } \\
(2016)\end{array}$ \\
\hline $\begin{array}{l}\text { Heading date } \\
\text { locus } 2 a\end{array}$ & RM7601 & $H d 2$ & 6 & $\begin{array}{l}\text { gectcgctgtcgct } \\
\text { aatatac }\end{array}$ & $\begin{array}{l}\text { cagcctctccttgt } \\
\text { gttgtg }\end{array}$ & 133bp & $\begin{array}{l}\text { Komiya et } \\
\text { al.(2008) }\end{array}$ \\
\hline $\begin{array}{l}\text { Heading date } \\
\text { locus } 3 a\end{array}$ & RM19414 & $H d 3$ & 6 & $\begin{array}{l}\text { gtcagaacttcaac } \\
\text { accaagg }\end{array}$ & $\begin{array}{l}\text { ctgtatagcttgat } \\
\text { ctaggagtagc }\end{array}$ & $504 \mathrm{bp}$ & $\begin{array}{c}\text { Anas et al., } \\
2010 \text { (tidak } \\
\text { di } \\
\text { publikasikan) }\end{array}$ \\
\hline $\begin{array}{l}\text { Kandungan } \\
\text { amilosa }\end{array}$ & RM190 & $W_{\boldsymbol{X}}$ & 6 & $\begin{array}{l}\text { ctttgtctatctcaa } \\
\text { gacac }\end{array}$ & $\begin{array}{l}\text { ttgcagatgttctt } \\
\text { cctgatg }\end{array}$ & $\begin{array}{l}104- \\
124 \mathrm{bp}\end{array}$ & $\begin{array}{l}\text { Chen et al. } \\
\text { (2008) }\end{array}$ \\
\hline $\begin{array}{l}\text { Temperatur } \\
\text { gelatinisasi } \\
\text { (TG) }\end{array}$ & SSIIa & SSIIa & 6 & $\begin{array}{l}\text { caaggagagctgg } \\
\text { agggggc }\end{array}$ & $\begin{array}{l}\text { acatgccgcgcac } \\
\text { ctggaaa }\end{array}$ & $\begin{array}{l}\text { 300bp } \\
\text { dan } \\
500 \mathrm{bp}\end{array}$ & $\begin{array}{l}\text { Jin et al. } \\
\text { (2010) }\end{array}$ \\
\hline $\begin{array}{l}\text { Tahan Wereng } \\
\text { cokelat }\end{array}$ & RM586 & $\begin{array}{l}\text { Bph3 } \\
\text { dan Bph } 4\end{array}$ & $\begin{array}{c}6 S \\
\text { dan } \\
6\end{array}$ & $\begin{array}{l}\text { acctcgcgttatta } \\
\text { ggtaccc }\end{array}$ & $\begin{array}{c}\text { gagatacgccaac } \\
\text { gagatacc }\end{array}$ & $271 \mathrm{bp}$ & $\begin{array}{l}\text { Jairin et al. } \\
\text { (2007a) }\end{array}$ \\
\hline $\begin{array}{l}\text { Tahan Wereng } \\
\text { cokelat }\end{array}$ & RM8213 & $\begin{array}{l}\text { Qbph 4, } \\
\text { Bph 17(t) }\end{array}$ & $\begin{array}{c}4 \\
\text { dan } \\
4 S\end{array}$ & $\begin{array}{l}\text { agcccagtgatac } \\
\text { aaagatg }\end{array}$ & $\begin{array}{c}\text { gcgaggagatacc } \\
\text { aagaaag }\end{array}$ & $177 b p$ & $\begin{array}{l}\text { Sun et al. } \\
\text { (2005) }\end{array}$ \\
\hline Aromatik & RM223 & Fgr & 8 & $\begin{array}{l}\text { gaaggcaagtctt } \\
\text { ggcactg }\end{array}$ & $\begin{array}{l}\text { gagtgagcttggg } \\
\text { ctgaaac }\end{array}$ & $\begin{array}{c}139-163 \\
\text { bp }\end{array}$ & $\begin{array}{l}\text { Kibria et } \\
\text { al. (2008) }\end{array}$ \\
\hline Aromatik & $\begin{array}{l}\text { IFAP dan } \\
\text { ESP }\end{array}$ & aroma & 8 & $\begin{array}{l}\text { cataggagcagct } \\
\text { gaaatatatacc }\end{array}$ & $\begin{array}{l}\text { ttgtttggagcttg } \\
\text { ctgatg }\end{array}$ & 257bp & $\begin{array}{c}\text { Bradbury } \\
\text { et al. } \\
(2005 \mathrm{~b})\end{array}$ \\
\hline Aromatik & $\begin{array}{l}\text { INSP dan } \\
\text { EAP }\end{array}$ & $\begin{array}{c}\text { Non } \\
\text { aroma }\end{array}$ & 8 & $\begin{array}{l}\text { ctggtaaaaagatt } \\
\text { atggcttca }\end{array}$ & $\begin{array}{l}\text { agtgctttacaaa } \\
\text { gtccegc }\end{array}$ & $355 \mathrm{bp}$ & $\begin{array}{c}\text { Bradbury } \\
\text { et al. } \\
\text { (2005b) }\end{array}$ \\
\hline
\end{tabular}

\section{HASIL DAN PEMBAHASAN}

Hubungan Kekerabatan Tetua dan Genotip Hasil Piramidisasi Berdasarkan Marka Molekuler

Genotip hasil piramidisasi dari berbagai tetua yaitu Sintanur, PTB-33, Pandanwangi, IR64, Ciapus, dan KA pada penelitian ini akan memunculkan keragaman genetik yang lebih besar. Hal ini karena penggabungan karakter target yang berasal dari hasil persilangan beberapa tetua selama beberapa generasi akan menghasilkan populasi heterozigot yang sangat tinggi (Kover et al., 2009; Shamim \& Singh, 2017). Keragaman yang tinggi akan menghasilkan nilai dendogram similarity yang rendah.

Dendogram pada Gambar 1 menunjukkan bahwa tingkat kemiripan antar tetua dan hasil piramidisasi berdasarkan marka molekuler yang diamati berkisar antara 0.00-4,13. Pada tingkat kemiripan 41,3\% terbentuk dua kelompok. 
Kelompok pertama dimulai dari genotipe SP, IP sampai PPxSP4B (kelompok pertama) dan SPxCAKA1B dan SPxPP3B (kelompok kedua). Genotipe SP memiliki jarak genetik yang jauh dengan SPxCAKA1B dan SPxPP3B. Semakin banyak persamaan pada marka molekuler yang dimiliki maka semakin besar nilai kesamaannya (similarity), yang menandakan hubungan kekerabatan yang semakin dekat. Sebaliknya, semakin banyak perbedaan karakter yang dimiliki maka semakin kecil nilai similaritasnya, yang menandakan semakin jauh hubungan kekerabatan antar genotip yang dibandingkan.

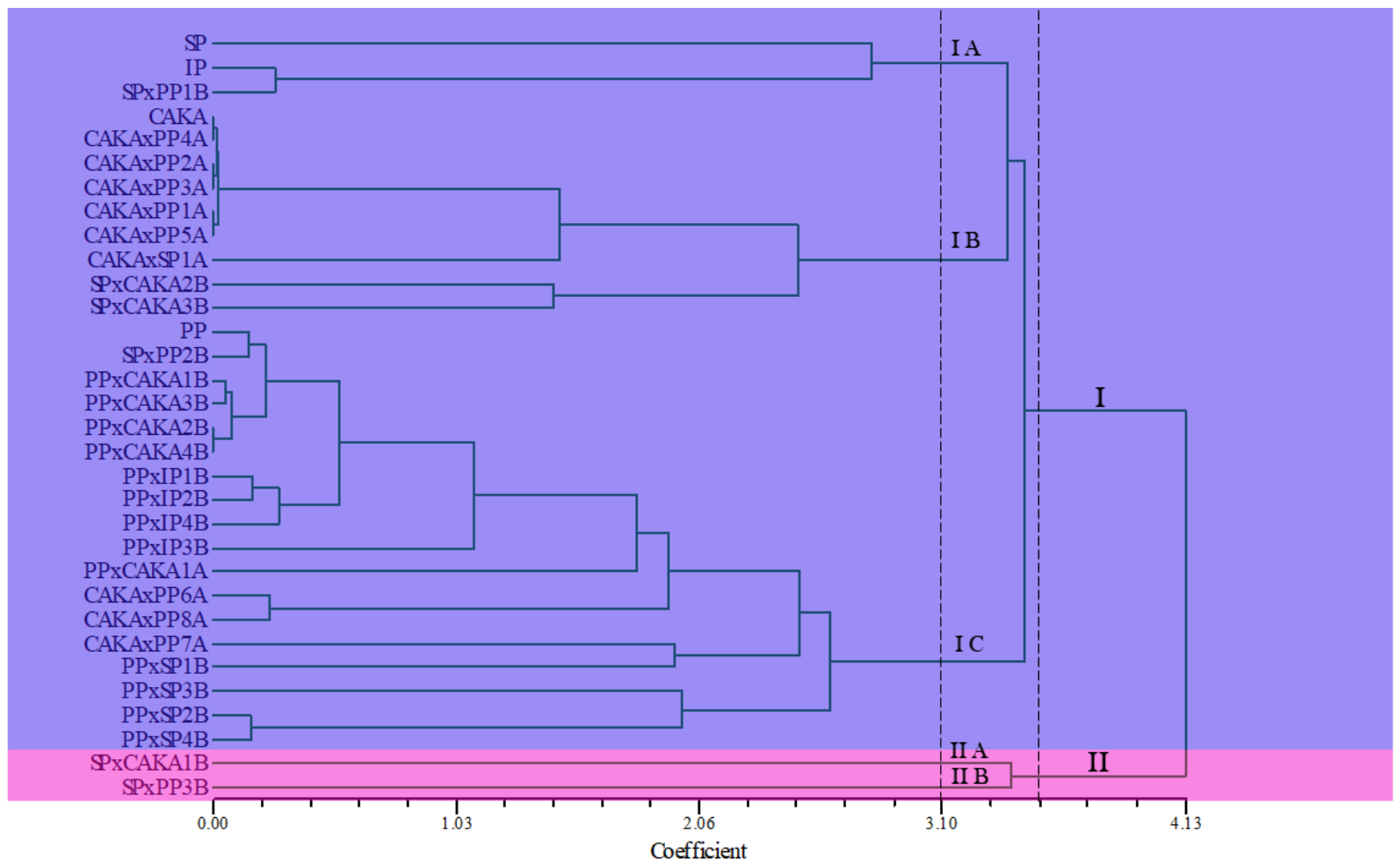

Gambar 1. Dendogram berdasarkan marka molekuler terkait karakter bobot bulir, jumlah malai, panjang malai, umur genjah, kandungan amilosa sedang, aromatik dan tahan wereng cokelat berdasarkan kemiripan genetik menggunakan software NTSYSpc 2.11X.

\section{Hubungan Kekerabatan Tetua dan Hasil Piramidisasi} Berdasarkan Marka Fenotipik

Dendogram hubungan kekerabatan berdasarkan marka fenotipik menunjukkan bahwa koefisien kemiripan antar tetua dan hasil piramidisasi yang diamati berkisar antar 0,23-2,22 (Gambar 2). Pada tingkat kemiripan 22,2\% terbentuk tiga kelompok. Kelompok pertama dari mulai genotip SP, SPxCAKA1B sampai CAKAxPP7A. Kelompok kedua dari mulai PPxCAKA4B sampai PPxSP3B, sedangkan PPxIP4B terpisah sendiri.

Genotip tetua SP, PP, IP dan CAKA serta beberapa genotipe hasil piramidisasi berada dalam satu kelompok (kel. 1). Pada kelompok ini, terdapat 2 genotip tetua SP dan PP, dimana varietas Sintanur dan Pandan wangi merupakan varietas lokal aromatik yang memiliki karakter agronomi yang mirip, berada pada satu kelompok yang sama. Hal ini juga ditandai dengan kemiripan karakter yang dimiliki genotip-genotip pada kelompok pertama, yaitu bobot bulir per rumpun, bobot bulir bernas per rumpun, bobot 100 biji, bobot pulir per malai, jumlah bulir per malai, panjang malai, jumlah anakan total, jumlah malai total, jumlah trikoma, aromatik dan umur panen.

Terdapat perbedaan nilai similarity antara marka molekuler (41,3\%) dan marka fenotipik $(22,2 \%)$ yang menandakan bahwa tingkat kemiripan genotip hasil seleksi marka molekuler lebih tinggi dibandingkan seleksi berbasis marka fenotipik. Hal ini dikarenakan karakter agro-morfologis dipengaruhi oleh faktor lingkungan seperti intensitas cahaya, kelembaban, dan serangan hama 
penyakit (Ahmad et al., 2015). Namun nilai dendogram dengan kemiripan di bawah 50\% dapat dikategorikan ke dalam genotip dengan variasi yang tinggi. Kondisi keragaman yang tinggi pada populasi hasil piramidisasi ini adalah didasari oleh pemilihan tetua yang digunakan. Tetua pada hasil piramidisasi pada penelitian ini merupakan varietas Indonesia dengan Pandan Wangi varietas lokal sedangkan tetua IR64 (rilis 1986), Sintanur (rilis 2001), dan Ciapus (rilis 2003) masih merupakan kelompok kultivar yang sama. Berdasarkan penelitian Daradjat et al. (2001) dikutip Anas dkk. (2004) menyatakan hampir semua kultivar padi Indonesia setelah tahun 1986 adalah kelompok padi IR64. Walaupun latar belakang genetiknya seperti ini, secara molekuler dan fenotipik menunjukkan tingginya tingkat variasi pada populasi hasil piramidisasi ini. Menurut Huang dan George (2011) semakin beragam wilayah geografis, genetik, dan fisiologis antar tetua yang akan digunakan dalam teknik piramidisasi maka akan semakin luas variasi yang akan terbentuk.

Perbedaan kelas yang terbentuk ditentukan oleh jarak genetik antar genotip pada populasi tersebut, yang artinya genotip yang terbentuk di dalam satu kelas memiliki jarak genetik yang lebih sempit (mirip). Santoso (2002) mengatakan individu yang diklasifikasikan dalam satu kelompok memiliki kemiripan satu dengan lainnya, sedangkan individu yang berada pada kelompok yang berbeda memiliki jarak genetik yang lebih jauh dibandingkan individu dalam satu kelompok yang sama. Semakin banyak persamaan karakter yang dimiliki maka semakin besar nilai similaritasnya, yang menandakan hubungan kekerabatan yang semakin dekat. Sebaliknya, semakin banyak perbedaan karakter yang dimiliki maka semakin kecil nilai similaritasnya, yang menandakan semakin jauh hubungan kekerabatan antar genotip yang dibandingkan

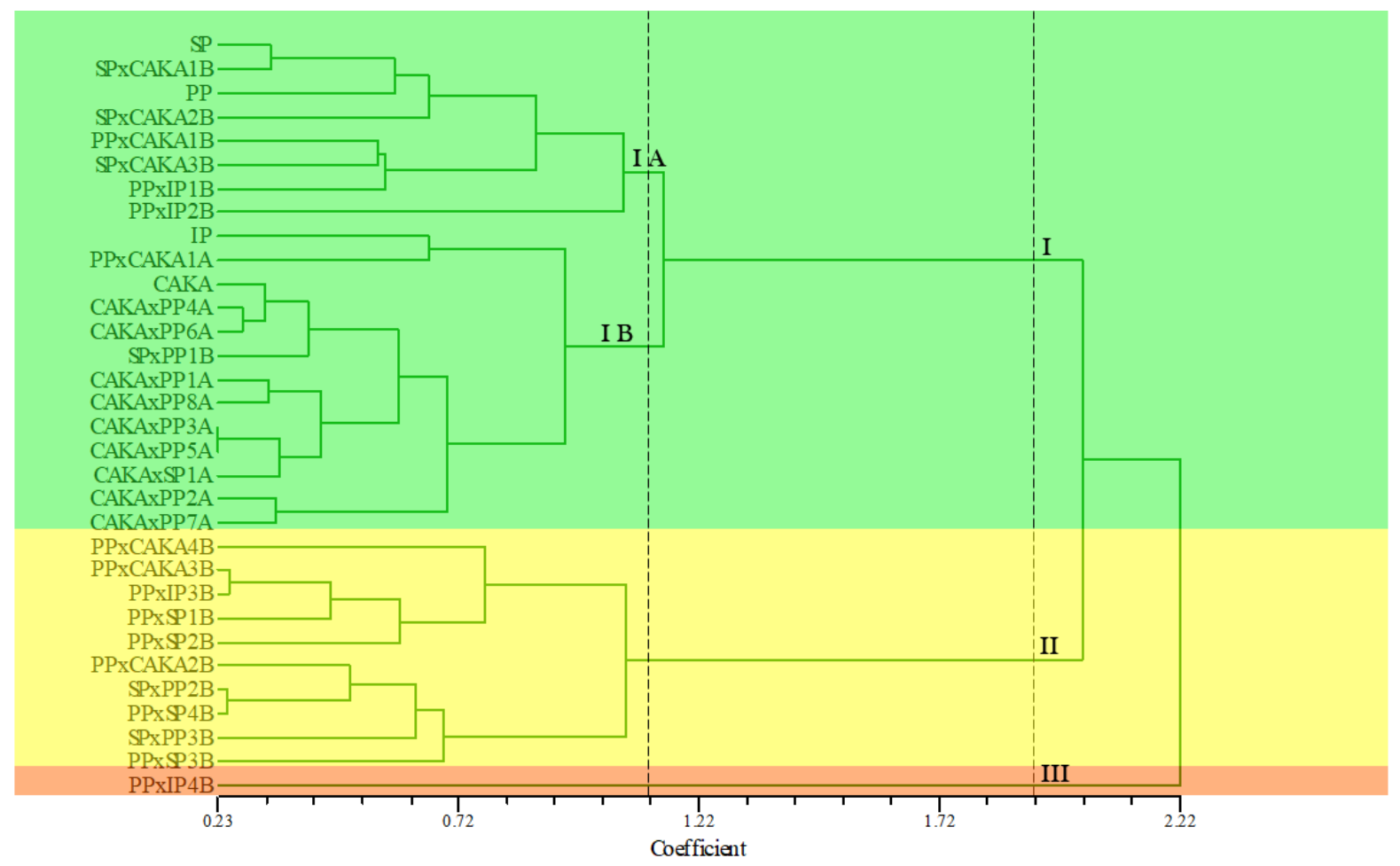

Gambar 2. Dendogram hasil analisis marka fenotipik terkait tinggi tanaman $(\mathrm{cm})$, jumlah anakan total, jumlah malai total, panjang malai (cm), jumlah bulir/malai (butir/malai), bobot bulir/malai (gram), bobot 100 butir (gram), bobot bulir bernas per rumpun (gram), umur bunting (HST), umur keluar amlai (HST), umur berbunga (HST), umur panen (HST), data aroma dengan uji sensori dan jumlah kerapatan trikoma.

Genotip SPxPP3B, SPxCAKA1B (Gambar 1) dan PPxIP4B secara fenotipik (Gambar 2), berada dalam kluster yang terpisah dengan genotip hasil piramidisasi lainnya, oleh karena itu dalam melakukan persilangan selanjutnya genotip tersebut, dapat dijadikan salah satu tetua dan dapat disilangkan dengan genotip lain yang memiliki jarak genetik yang jauh. Varietas yang memiliki 
perbedaan karakter yang jauh dapat diasumsikan juga memiliki hubungan kekerabatan yang jauh, sehingga apabila disilangkan akan menghasilkan keturunan yang lebih baik daripada rata-rata kedua tetuanya (Sitaresmi dkk., 2018). Salah satu karakter yang khas dari genotip PPxIP4B adalah memiliki total anakan terbanyak yaitu 111 batang/rumpun. Menurut Satoto dan Suprihatno (1998) sifat kuantitatif yang diamati secara visual dipengaruhi oleh lingkungan, dan masing-masing genotip mempunyai respon yang berbeda terhadap daya dukung lingkungan.

\section{SIMPULAN}

Berdasarkan hasil analisis kekerabatan padi hasil piramidisasi melalui marka molekuler dan marka fenotipik diperoleh nilai dendogram marka molekuler pada tingkat kemiripan $41,3 \%$ terbentuk dua kelompok dan dendogram marka fenotipik pada tingkat kemiripan 22,2\% terbentuk tiga kelompok. Genotip SPxCAKA1B, SPxPP3B dan PPxIP4B memiliki jarak genetik yang lebih jauh dibandingkan denga genotip lainnya, sehingga dapat dijadikan sebagai tetua atau genotip harapan bagi pengembangan program pemuliaan tanaman berikutnya.

\section{UCAPAN TERIMAKASIH}

Ucapan terima kasih disampaikan kepada Kemristekdikti 2018 atas bantuan biaya hibah penelitian atas nama Nono Carsono.

\section{DAFTAR PUSTAKA}

Ahmad, F, MM Hanafi, MdA Hakim, MY Rafii, IW Arolu, and SNA Abdullah. 2015. Genetic divergence and heritability of 42 coloured upland rice genotypes (Oryza sativa) as revealed by microsatellites marker and agro-morphological traits. PLOS ONE. 13: 1-18.

Anas, N Carsono, dan S Utomo. 2004. Hubungan latar belakang genetik plasma nutfah padi Indonesia dengan umur sangat genjah (90104) dan toleran kekeringan (-30 Kpa). Laporan Hasil Penelitian KKP3T. Tidak dipublikasikan.

Badan Pusat Statistik. 2015. Produksi Padi, Jagung, dan Kedelai. BPS Jakarta. Tersedia online pada https://www.bps.go.id. (Diakses 21 Agustus 2019).
Bahagiawati. 2012. Kontribusi teknologi marka molekuler dalam pengendalian wereng cokelat. Pengembangan Inovasi Pertanian 5: 1-18.

Balai Besar Penelitian Tanaman Padi. 2011. Deskripsi Varietas Padi. Badan Penelitian dan Pengembangan Pertanian. Kementerian Pertanian.

Bennett, SJ. 1997. A phonetic analysis and leteral key of the genus Lolium (Gamninae). Genet Resour Cop Ev. 44: 63-72.

Bradbury, LMT, TL Fitzgerald, RJ Henry, Q Jin, and DLE Waters. 2005. The gene for fragrance in rice. Plant Biotech J. 3: 363-370.

Carsono, N, A Zaelani, dan M Rachmadi. 2012. Identifikasi gen kegenjahan padi generasi $\mathrm{F}_{2}$ hasil persilangan kultivar Ciapus X Kitaake menggunakan dua marka SSR serta korelasinya dengan karakter umur keluar malai. Prosiding Seminar Seminar Nasional, Peran Sumber Daya Genetik dan Pemuliaan Dalam Mewujudkan Kemandiriaan Industri Perbenihan Nasional dalam Kongres PERIPI. Bogor.

Carsono, N, YV Barus, S Sari, WD Widarmi, D Dono, Y Sumekar, and Murdaningsih. 2013. Identification of polymorphism of Simple Sequence Repeats markers that associated with resistance genes to brown planthoppers (Nilaparvata lugens) and its genetic relationship in twenty rice genotypes. Proceeding of International Biology Conference UGM. September 2013.

Carsono, N, PI Prayoga, N Rostini, dan D Dono. 2016. Seleksi berbasis marka molekuler pada padi generasi $F_{2}$ guna merakit galur padi harapan tahan wereng coklat. Jurnal Agrikultura. 27(1): 9-15.

Chen, S, Y Yang, W Shi, Q Ji, F He, Z Zhang, Z Cheng, X Liu, and M Xu. 2008. Badh2, encoding betaine aldehyde dehydrogenase, inhibits the biosynthesis of 2-acetyl-1pyrroline, a major component in rice fragrance. The Plant Cell. 20: 1850-1861.

Collard, BCY, and DJ Mackill. 2008. Marker-assisted selection: an approach for precision plant breeding in the twenty-first century. Phil. Trans. R. Soc. Lond B Biol Sci. 363 (1491): 557-572.

Doyle, JJ, and JL Doyle. 1987. Isolation of plant DNA from fresh tissues. Focus. 12: 13-15.

Fan, CC, XQ Yu, YZ Xing, CG Xu, LJ Luo, and Q Zhang. 2005. The main effects, epistatic 
effects and environmental interactions of QTLs on the cooking and eating quality of rice in a doubled-haploid line population. Theoretical and Applied Genetics. 110: 1445-1452.

Francis, DM, HL Merk, and DN Covert. 2013. Gene pyramiding using molecular markers. United Stated. The Ohio State University and University of Nebraska-Linconl. Available online at http://www.extension.org/. (Accessed 24 June 2019).

Gramene. 2016. Oryza Taxonomi. Available online at

http://www.gramene.org/species/oryza/rice _taxonomy.html. (Accessed 24 June 2019).

Hittalmani, S, A Parco, TV Mew, RS Zeigler, and N Huang. 2000. Fine mapping and DNA marker-assisted pyramiding of the three major genes for blast resistance in rice. Theor Appl Genet 100:1121-1128. Available online

https://doi.org/10.1007/s001220051395.

(Accessed 2 July 2019).

Huang, BE, and AW George . 2011. R/mpMap: a computational platform for the genetic analysis of multi-parent recombinant inbred lines. Bioinformatics. 27: 727-729.

IBPGRI-IRRI Rice Advisory Committee. 1980. Descriptors for Rice (Oryza sativa. L). International Rice Research Institute and International Board for Plant Genetic Resources. Philippines. P. 21.

IRRI. 2009. The Quality Characteristic of Milled Rice are Classified Both Physically and Chemically. Available online at http://www.knowledgebank.irri.org/rkb/ind ex.php/quality-characteristics-of-milledrice. (Accessed 24 June 2019).

Jairin, J, K Phengrat, S Teangdeerith, A Vanavichit, and T Toojinda. 2007. Mapping of a broadspectrum brown planthopper resistance gene, Bph3, on rice chromosome 6. Mol Breeding. 19: 35-44.

Jin, L, Y Lu, Y Shao, G Zhang, P Xiao, S Shen, H Corke, and J Bao. 2010. Molecular marker assisted selection for improvement of the eating, cooking and sensory quality of rice (Oryza sativa L.). Journal of Cereal Science. 51: 159-164.

Joseph, M, S Gopalakrishnan, RK Sharma, VP Singh, AK Singh, NK Singh, T Mohapatra, 2004. Combining bacterial blight resistance and
Basmati quality characteristics by phenotypic and molecular marker-assisted selection in rice. Molecular Breeding. 13: 377-387.

Kover, PX, W Valdar, J Trakalo, N Scarcelli, IM Ehrenreich, MD Purugganan, C Durrant, and R Mott. 2009. A multiparent advanced generation inter-cross to fine-map quantitative traits in Arabidopsis thaliana. PLoS Genetics. 5(7): 1-15.

Lan, W, and W Chao. 2011. Application of molecular marker assisted selection in gene pyramiding and selection of new cultivars. Journal of Northeast Agricultural University. 18(1): 7984.

Mattjik, AA, dan IM Sumertajaya. 2006. Perancangan Percobaan dengan Aplikasi SAS dan Minitab. Edisi ke-2. IPB Press. Bogor.

Kanagarasu, S, G Nallathambi, KN Ganesan, S Kannan, VG Shobhana, and N Senthil. 2013. Determination of genetic polymorphism among indigenous and exotic maize inbreds using microsatellite markers. African Journal of Biotechnology. 12(39): 57235728.

Katiyar, SK, Y Tan, B Huang, G Chandel, Y Xu, Y Zhang, Z Xie, and J Bennett. 2001. Molecular mapping of gene Gm-6(t) which confers resistance against four biotypes of Asian rice gall midge in China. Theor Appl Genet. 103: 953-961.

Kusmana, A, A Budiman, dan A Hidayat. 2017. Perkembangan Produksi dan Konsumsi Pangan di Indonesia. Munich Personal RePEc Archive. Tersedia online pada https://mpra.ub.uni-muenchen.de/79976/. (Diakses10 Agustus 2019).

Komiya, R, A Ikegami, S Tamaki, S Yokoi, and K Shimamoto. 2008. Hd3a and RFT1 are essential for flowering in rice. Development. 135: 767-774.

Kumaravadivel, N, MD Uma, PA Saravanan, and H Suresh. 2006. Molecular marker-assisted selection and pyramiding genes for gall midge resistance in rice suitable for Tamil Nadu Region. In Abstracts- 2nd International Rice Congress 2006. p. 257.

Narayanan, NN, N Baisakh, CM Vera Cruz, SS Gnanamanickam, K Datta, and SK Datta. 2002. Molecular breeding for the development of Blast and Bacterial Blight 
resistance in Rice cv.IR50. Crop Sci. 42: 2072-2079.

Pink, D, and Puddephat. 1999. Deployment of disease resistance genes by plant transformation - a 'mix and match' approach. Plant Science. 4(2): 71-75.

Rajpurohit, DA Awasthi, R Kumar, PO Basha, HS Dhaliwal, M Kumar, A Puri, P Paul, T Jhang, and K Singh. 2011. Pyramiding of two bacterial blight resistance and a semidwarfing gene in Type 3 Basmati using marker-assisted selection. Euphytica. 178: 111-126.

Sari, S, HK Murdaningsih, dan N Carsono. 2013. Seleksi Tanaman Padi $\mathrm{F}_{2}$ yang Memiliki Karakter Aroma, Pengapuran Biji dan Kadar Amilosa Berdasarkan Marka Fenotipe dan Molekuler. [Tesis]. Fakultas Pertanian, Universitas Padjadjaran. Bandung.

Satoto, dan B Suprihatno. 1998. Heterosis dan stabilitas hasil hibrida-hibrida padi turunan galur mandul jantan IR62829A dan IR58025A. Penel. Pertanian Tanaman Pangan. 17(1): 33-37.

Santoso, S. 2002. Buku Latihan SPSS Statistik Multivariat. Elex Media Komputindo. Jakarta. p. 342.

Shamimm, Md, and KN Singh. 2017. Biotic Stress Management in Rice. Apple Academic Press Inc. Oakville. p. 17.

Sharma, PN, A Torii, S Takumi, N Mori, dan C Nakamura. 2004. Marker-assisted pyramiding of brown planthopper (Nilaparvata lugens Stall) resistance genes Bph1 and Bph2 on rice chromosome 12 . Hereditas. 140: 61-69.

Singh, S, JS Sidhu, N Huang, Y Vikal, Z Li, DS Brar, HS Dhaliwal, and GS Khush. 2001. Pyramiding three bacterial blight resistance genes (xa5, xa13 and Xa21) using marker- assisted selection into indica rice cultivar PR106. Theor Appl Genet. 102: 1011-1015.

Sitaresmi, T, N Yunani, Nafisah, Satoto, dan AA Daradjat. 2018. Analisis kemiripan morfologi varietas unggul padi periode pelepasan 1980-2011. Buletin Plasma Nutfah. 24(1): 31-42.

Sood, BC and EA Siddiq. 1978. A rapid technique for scent determination in rice. Indian J Genet Plant Breed. 38: 117-124.

Sundaram, RM, MR. Vishnupriya, GS Laha, NS Rani, SM Balachandran, GA Reddy, NP Sarma, PS Rao, and RV Sonti. 2009. Introduction of bacterial blight resistance into Triguna, a high yielding, mid-early duration rice variety. Biotechnol J. 4(3): 400-407.

Sun, L, C Su, C Wang, H Zai, and J Wan. 2005. Mapping of a major resistance gene to brown planthoPP48-3er in the rice cultivar Rathu Heenati. Breed. Sci. 55: 391396.

Tambunan, R, N Carsono, dan N Wicaksana. 2017. Piramidisasi Gen untuk Karakter Komponen Hasil, Umur Genjah, Kualitas Mutu Beras serta Tahan terhadap Wereng Cokelat pada Padi Berdasarkan Marka Molekuler dan Fenotipik. [Tesis]. Fakultas Pertanian, Universitas Padjadjaran. Bandung.

Weeden, NF, and JF Wendel. 1989. Genetics of plant isozymes. Pp. 46-72 in Isozymes in Plant Biology (DE Soltis, PS Soltis, Eds.). Dioscorides Press. Portland, Oregon.

Ye, G, and KF Smith. 2008. Marker-assisted gene pyramiding for inbred line development: Basic principles and practical guide. International Journal of Plant Breeding. 2: 1-10. 